\title{
PENGARUH DEWAN KOMISARIS INDEPENDEN, KOMITE AUDIT, KUALITAS AUDIT, KEPEMILIKAN MANAJERIAL DAN DIVIDEND PAYOUT RATIO TERHADAP PERATAAN LABA
}

\author{
Restu Rahmini \\ Universitas Bina Nusantara \\ resturahmini55@gmail.com \\ Rosinta Ria Panggabean \\ Universitas Bina Nusantara \\ rosinta_ria_panggabean@binus.ac.id
}

Diterima 27 Januari 2020

Disetujui 10 Februari 2020

\begin{abstract}
The purpose of this study is to analyse the influence of the Independent Board of Commissioners, Audit Committee, Audit Quality, Managerial Ownership and Dividend payout ratio on income smoothing and dompany size as a control variabel. The sample in this study are Property and Real Estate sector companies listed on the Indonesia Stock Exchange (BEI) and Bursa Malaysia (KESE) in 2014-2017. This study used purposive sampling method, logistic regression analysis, and classic assumption test. Income smoothing can be measured using dummy variabels. The Independen Board of Commissioners, Audit Committee, Audit Quality, managerial ownership, Dividend payout ratio and company size have no effect on income smoothing on the Indonesia stock Exchange securities, while the results of the analysis show that the vaxiabels that affect income smoothing on the Bursa Malaysia are managerial ownership and control variabels, namely the size of the companies
\end{abstract}

listed.
Keywords: Audit Committee, Audit Quality, Mangerial Qwnership, Dividend payout ratio
, Income smoothing.

\section{PENDAHULUAN}

Laporan keuangan merupakan sarana untuk pengambilan keputusan ekonomi berbagai pihak. Para investor dalam memutuskan berinvestasi perlu melakukan evaluasi kinerja manajemen, meramalkan laba, menaksir tingkat risiko investasi dengan sarana laporan keuangan ini. Oleh karena itu manajemen perusahaan akan berusaha untuk menampilkan kinerja keuangan terbaiknya. Manajemen perusahaan cenderung melakukan manipulasi laba untuk menunjukkan kinerja keuangan yang stabil dengan perataan laba. Menurut Belkaoui (2006:73), perataan laba adalah pengurangan fluktuasi laba dari tahun ke tahun dengan memindahkan pendapatan dari tahun-tahun yang tinggi pendapatannya ke periode-periode yang kurang menguntungkan. Lebih lanjut dijelaskan bahwa perataan laba sebagai fenomena proses manipulasi profil waktu dari pendapatan atau laporan laba menjadi kurang bervariasi, sambil sekaligus tidak meningkatkan pendapatan yang dilaporkan selama periode tersebut.

Di dalam laporan keuangan terdapat informasi mengenai laba, dan setiap perusahaan tentu akan berusaha untuk meningkatkan laba mereka. Menurut Subramanyam (1996) salah satu ukuran kinerja perusahaan yang sering digunakan sebagai dasar pengambilan keputusan 
adalah laba yang dihasilkan perusahaan, laba tersebut diukur dengan dasar akrual. Seringkali informasi penting mengenai laba menjadi target untuk direkayasa dengan cara meningkatkan penjualan ataupun dengan cara menurunkan harga pokok penjualan sehingga laba akan naik. Laba yang meningkat akan mempengaruhi investor untuk membeli saham perusahaan sehingga dapat menguntungkan manajemen dan akan berujung kerugian bagi investor dan publik akibat dari manipulasi yang dilakukan oleh manajemen. Laporan sebagai produk informasi yang dihasilkan perusahaan tidak terlepas dari proses penyusunannya. Proses penyusunan laporan ini melibatkan pihak pengurus dalam pengelolaan perusahaan, diantaranya adalah pihak manajemen, dewan komisaris, dan pemegang saham. Kebijakan dan keputusan yang diambil oleh mereka dalam rangka proses penyusunan laporan keuangan. Laporan keuangan yang berkualitas memiliki kemampuan untuk memberikan informasi kepada pasar yang berarti laporan keuangan memiliki daya informasi (Wawo, 2014).

Manajemen laba merupakan suatu intervensi dengan memiliki tujuan dan maksud tertentu dalam proses penyusunan laporan keuangan eksternal untuk memperoleh keuntungankeuntungan pribadi bagi pihak tertentu. Manajemen laba dapat dijelaskan melalui teori keagenan. Agen yang dimaksud adalah manajemen. Manajemen tentu mengetahui berbagai kondisi yang terdapat didalam suatu perusahaan. Mulai dari operasional, permasalahan hingga masa depan perusahaan tersebut. Dalam hal ini, manajemen memiliki tanggung jawab terhadap pemilik perusahaan mengenai kinerja perusahaanya. Manajemen tentu tidak ingin terlihat memiliki kinerja buruk dalam menjalankan perusahaan. Selain itu manajemen juga bertanggung jawab untuk memaksimalkan keuntungan perusahaan bagi pemiliknya dan tentu manajemen akan mendapatkan menjelaskan bagaimana manaje memiliki beberapa bentuk yaitu, income smoothing, bentuk manaj laporan keuangan eksternal bagi investor-(Scott, 2003:405). Salah satu bentuk manajemen laba adalah perataan laba atau income smoothing. Tindakan manajer meratakan laba adalah untuk membuat arus penghasilan stabil dan mengurangi covarian return dengan pasar.

Marpaung dan Latrini (2014) menelit tentang pengafth dewan komisaris independen, komite audit, kualitas audit, kepemilikan ntanajortal terhadap perataan laba. Dan menggunakan sampel purpose sampling dengan objek penelitian perusahaan manufaktur yang terdaftar di BEI periode 2009-2012 serta mengguakan regresi logistik sebagai alat analisis data. Hasil dari penelitian ini menemukan bahwa dewan komisaris independen tidak berpengaruh terhadap perataan laba, namun penelitian Nabila dan Daljono (2013) yang meneliti topik yang sama menunjukkan hasil yang berbeda dimana dewan komisaris independen berpengaruh negatif terhadap manajemen laba. Dikarenakan bahwa dewan komisaris memegang peranan penting dalam menjamin pelaksanaan strategi perusahaan, mengawasi manajemen dalam mengelola perusahaan, serta mewajibkan terlaksananya akuntabilitas. Dalam prakteknya, di Indonesia sering terjadi anggota dewan komisaris sama sekali tidak menjalankan peran pengawasannya yang sangat mendasar terhadap dewan direksi. Dewan Komisaris seringkali dianggap tidak memiliki manfaat, hal ini dapat dilihat dalam fakta, bahwa banyak anggota Dewan Komisaris tidak memiliki kemampuan dan tidak dapat menunjukkan independensinya.Dalam banyak kasus, Dewan Komisaris juga gagal untuk mewakili kepentingan stakeholders.

Penelitian yang dilakukan Pradana, Khairunnisa dan Khirisna (2016) menunjukkan bahwa komite audit tidak berpengaruh terhadap perataan laba, namun, hasil penelitian yang berbeda ditemukan oleh Yendriwati (2015) yang menyatakan bahwa komite audit berpengaruh terhadap tindakan perataan laba. Dikarenakan Komite Audit adalah komite yang 
dibentuk oleh dewan komisaris yang bekerjasama untuk membantu melaksanakan tugas dan fungsi dewan komisaris yakni melaksanakan pengawasan atas pengelolaan perusahaan oleh direksi. Satu elemen penting dalam pengawasan oleh dewan komisaris adalah bekerjasama erat dengan direksi dan manajemen perusahaan untuk mewujudkan kepatuhan perusahaan terhadap hukum dan standar etika. Pengawasan ini mencakup upaya untuk memastikan bahwa perusahaan memiliki kebijakan akuntansi, pengendalian internal, dan akuntan publik independen dan objektif yang dapat mengidentifikasi adanya fraud, mengantisipasi risikorisiko, dan memastikan bahwa informasi yang dikeluarkan perusahaan kepada pemegang saham dan publik adalah benar.

Dalam hal ini menurut Gerayli et al. (2011) dan Marpaung et al. (2014) kualitas audit dapat di ukur dengan ukuran KAP (KAP big-four dan KAP non big-four). Berdasarkan penelitian sebelumnya, Marpaung dan Latrini (2014) menemukan bahwa kualitas audit berpengaruh secara negatif signifikan terhadap perataan laba. Menurut Wijoyo (2014) menyatakan bahwa kualitas audit berpengaruh positif signifikan terhadap perataan laba. Namun menurut Lidiawati dan Asyik (2016) kualitas audit tidak berpengaruh signifikan terhadap perataan laba. Kualitas Audit, dalam pemberian opini audit oleh auditor harus dilakukan terlebih dahulu pemeriksaan terhadap transaksi-transaksi perusahaan. Selama pengujian dan pemeriksaan auditor akan menentukan apakah pencatatan untuk laporan keuangan telah sesuai dengan standar akuntansi yang berlaku umum.Selain itu auditor akan memeriksa apakah transaksi yangtelah dicatat sesuai dengan waktu pengakuan dari transaksi tersebut. Sehingga semakin baik opini yang didapat perusahaan tentu tindakan manajemen
lama semakin kecil.

Penelitian Pratama (20 manajerial berpengaruh negatif signifikan terh bertentangan dengan Marpaung dan Latrini (2014) yang menyatakan bahwa kepemilikan
manajerial tidak berpengaruh signifikan terhadap perataan laba. Bahwa kepemilikan manajerial mempunyai arti bahwa kepemilikan perusahaan juga dimiliki oleh manajemen. Hal ini diharapkan agar manajer memiliki pemikiran yang sama sebagai pemilik dan berusaha untuk menjalankan perusahaan sesuai dengan aturan yang berlaku dan memiliki etos kerja yang tinggi sehingga pengawasan terhadap pérusahaan akan lebih baik. Dampak dari kepemilikan manajerial yang diharapkan adalah/laporan keuangan yang dihasilkan memiliki independesi dan sesuai dengan aturan yang berlaku. Kepemilikan Manajerial dapat diukur dengan cara menghitung jumlah persentase saham yang dimiliki manajemen dari jumlah saham yang beredar.

Dividend payout ratio adalah persentase pendapatan atau laba yang akan dibayarkan kepada pemegang saham sebagai kas dividen. Besar kecilnya laba akan mempengaruhi besar kecilnya dividen yang akan dibagikan pada para pemegang saham. Investor akan tertarik dengan besarnya dividen yang diberikan oleh perusahaan, dan kecilnya risiko yang akan diterima oleh investor tersebut. Salah satu upaya perusahaan untuk meyakinkan investor bahwa risiko yang ada dalam perusahaan kecil, adalah dengan melakukan perataan laba, jika perusahaan bisa membagikan dividen yang tinggi, berarti laba pada perusahaan tersebut bisa dikatakan besar, jika dalam kondisi laba yang tinggi tetapi laba yang diperoleh perusahaan tidak terus menerus atau bisa dikatakan tidak stabil yang berarti risiko pada perusahaan tinggi, maka perusahaan akan melakukan perataan laba (Abiprayu, 2011).

Berdasarkan uraian tersebut, rumusan masalah dalam penelitian ini adalah sebagai berikut: apakah dewan komisaris independen, komite audit, kualitas audit, kepemilikan manajerial, dan Dividend payout ratio berpengaruh terhadap perataan laba yang terdaftar di Bursa Efek Indonesia (BEI) dan Bursa Malaysia (KLSE). Tujuan dari penelitian ini adalah 
untuk menganalisa pengaruh dewan komisaris independen, komite audit, kualitas audit, kepemilikan manajerial, dan Dividend payout ratio berpengaruh terhadap perataan laba yang terdaftar di Bursa Efek Indonesia (BEI) dan Bursa Malaysia (KLSE). Sedangkan manfaat dari penelitian ini diharapkan dapat menjadi acuan dalam pengawasan yang lebih ketat dalam operasional perusahaan sehingga praktik perataan laba dapat diminimalisir

\section{Tinjauan Literatur dan Hipotesis}

Suwardjono (2014:485-486) mendasarkan teori keagenan atas dasar berbagai aspek dan implikasi hubungan keagenan. Hubungan keagenan adalah hubungan antara principal (principal) dan agen (agent) yang di dalamnya agen bertindak atas nama dan untuk kepentingan prinsipal dan atas tindakannya (actions) tersebut agen mendapatkan imbalan tertentu. Dalam konteks pelaporan keuangan, hubungan antara investor dan manajemen dikarakteristikkan sebagai hubungan keagenan; pemegang saham sebagai prinsipal dan manajemen sebagai agen.

Dalam teori keagenan Jensen dan Meckling (1976) dapat terjadi konflik kepentingan antara agen atau manajer dan prinsipal atau pemilik perusahaan yang dapat memicu terjadinya biaya keagenan. Untuk dapat membatasi-tindakan-menyimpang manajer (agent) yang tidak sesuai dengan keinginan pemilik perusahaan (principal) maka dapat dilakukan dengan memberikan insentif yang tepat kepada manajer dan dengan mengeluarkan biaya monitoring yang didesain untuk membatasi kegiatan yang menyimpang dari manajer. Sebagai tambahan dalam beberapa situasi, agen akan-mengeluarkan biaya perikatan (bonding cost) dari sumberdaya perusahaan sebagai jaminan bagi-pemilik perusahaan bahwa manajer tidak akan melakukan tindakan yang merugikan pemilik perusahaan atau untuk memastikan bahwa pemilik perusahaan akan diberikan kompensasi apabila manajer mengambilkan tindakan seperti itu. Pada kebanyakan hubungan keagenan antara manajer dan pemilik perusahaan akan dikenakan biaya monitoring dan biaya perikatan, dan disamping itu juga terdapat perbedaan antara keputusan manajer dan keputusan tersebut akan meningkatkan kesejahteraan bagi pemilik perusahaan. Nilai mata uang yang setara dengan pengurangan kesejahteraan bagi pemilik perusahaan (principal) akibat dariperbedaan keputusan tersebut disebut sebagai biaya kerugian residual (residual loss)

Dewan komisaris independen adalah anggota dewan komisaris yang tidak terafiliasi dengan manajemen, anggota dewan komisaris lainnya dan pemegang saham pengendali, serta bebas dari hubungan bisnis atau hubungan lainnya yang dapat mempengaruhi kemampuannya untuk bertindak independen atau bertindak semata - mata demi kepentingan perusahaan. Keberadaan komisaris independen dalam perusahaan berfungsi sebagai penyeimbang dalam proses pengambilan keputusan yang memihak kepada pemegang saham minoritasdan pihakpihak lain yang berhubungan dengan perusahaan. Menurut Isnanta (2008), yang menyatakan bahwa Dewan komisaris independen berpengaruh terhadap praktek laba. Hasil penelitian yang sama juga dinyatakan oleh Tiswiyanti, Fitriyani \& Wiralestari (2012), bahwa Dewan Komisaris independen berpengaruh terhadap manajemen laba. Hasil penelitian yang berbeda ditemukan oleh Mapaung dan Latrini (2014), yang menyatakan bahwa dewan komisaris independen tidak berpengaruh secara signifikan terhadap perataan laba. Berdasarkan teori dan hasil penelitian sebelumnya maka, dapat disimpulkan bahwa :

H1: Dewan komisaris independen berpengaruh terhadap perataan laba pada perusahaan property dan real estate yang terdaftar di BEI tahun 2014-2017.

H6: Dewan komisaris independen berpengaruh terhadap perataan laba pada perusahaan property dan real estate yang terdaftar di KLSE tahun 2014-2017. 
Komite audit memiliki tanggung jawab pengawasan untuk proses pelaporan keuangan perusahaan dan tujuan utamanya adalah untuk meningkatkan kredibilitas laporan yang diaudit. Pada prinsipnya, tugas dari komite audit adalah untuk memberikan rekomendasi kepada dewan komisaris untuk kondisi pelaksanaan peraturan perundang-undangan kegiatan perusahaan dan melakukan penelaahan untuk laporan keuangan perusahaan (Putri, 2011). Komite audit menurut Sari (2008) bertanggungjawab untuk mengawasi laporan keuangan, mengawasi audit internal, dan mengamati system pengendalian internal dapat mengurangi sifat oppurtunistic manajemen yang melakukan manajemen laba dengan cara mengawasi fungsi perusahaan dari dalam perusahaan secara lebih independen. Menurut Mapaung dan Latrini (2014) Komite Audit tidak berpengaruh secara signifikaan terhadap perataan laba. Gusnadi dan Budiharta (2008) menemukan hal yang sama bahwa Komite audit tidak berpengaruh terhadap perataan laba. Berbeda dengan penelitian yang dilakukan oleh Wiwik, Dewi dan Wiralestari (2012) bahwa Komite audit memiliki pengaruh terhadap manajemen laba. Hasil yang sama ditemukan oleh Tampubolon (2012) menunjukkan bahwa komite audit berpengaruh terhadap perataan laba. Dengan demikian adanya komite audit dalam suatu perusahaan dapat mempengaruhi manajemen untuk-melakukan aktivitas manajemen laba riil. Dari hasil penelitian di atas bahwa peneliti ada yang mengatakan komite audit berpengaruh terhadap perataan laba dan ada juga yang menyatakan bahwa komite audit tidak berpengaruh terhadap perataan laba. Maka darfitu peneliti ingin meneliti kembali tentang pengaruh komite audit terhadap perataan laba terseb

\section{H2: Komite audit berpengaru real estat \\ H7: Komite audit berpengaruh terhad real estate ya

$$
\text { had ap }
$$

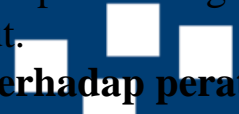
aftar di BEI tahun 2014-2017.

pada perusahaan property dan

Kualitas audit memiliki arti berbeda bagi pemakai atau penerima dan pemeriksa laporan keuangan. Bagi pemakai atau penerima, kualitas audit yang baik memiliki arti laporan keuangan yang digunakan atau dỉbentuk sesuai dengan standar akuntansi yang berlaku umum. Sedangkan bagi auditor, kualitas audit yang baik/merupakan suatu pencapaian auditor dalam menemukan risiko bisnis dan audit sehingga dapatmeminimalisir risiko litigasi sehingga tidak terjadi kesalahan pemberian opini dan mampu nenghindari risiko reputasi KAP. Menurut Gerayli et al (2011) dan Marpaung et al (2014) kualitas audit dapat di ukur dengan ukuran KAP (KAP big-four dan KAP non big-four).

Menurut Marpaung dan Latrini (2014) kualitas audit yang diukur dengan ukuran KAP berpengaruh signifikan terhadap praktik perataan laba. Karena KAP yang memiliki reputasi yang baik seperti KAP big-four akan mampu mendeteksi kesalahan dalam laporan keuangan. Hal ini juga didukung dengan pernyataan DeAngelo (1981) yang menyatakan bahwa KAP big-four memberikan kualitas audit yang lebih baik di bandingkan KAP non-big four. KAP besar seperti KAP big-four memiliki lebih banyak sumber daya dan lebih banyak klien sehingga mereka tidak tergantung pada satu atau beberapa klien saja. Selain itu, karena reputasinya yang telah dianggap baik oleh masyarakat menyebabkan mereka akan melakukan audit dengan lebih teliti dan cermat. Oleh sebab itu, maka kualitas audit berpengaruh signifikan terhadap perataan laba. Hal ini dapat diartikan bahwa semakin baik kualitas audit maka praktik perataan laba akan mampu diminimalisir. Menurut Arief (2016) kualitas audit berpengaruh simultan terhadap perataan laba dan menurut Ingrid dan Yeterina, kualitas audit tidak berpengaruh terhadap manajemen laba. Hal ini dimungkinkan praktik manajemen laba terjadi karena perusahaan memiliki keinginan agar kinerja keuangan perusahaan tampak 
bagus dimata calon investor, namun mengabaikan keberadaan auditor Big- 4 (Luhgiatno 2010).

\section{H3: Kualitas audit berpengaruh terhadap perataan laba pada perusahaan property dan real estate yang terdaftar di BEI tahun 2014-2017.}

H8: Kualitas audit berpengaruh terhadap perataan laba pada perusahaan property dan real estate yang terdaftar di KLSE tahun 2014-2017.

Berdasarkan teori keagenan menurut Jensen dan Meckling (1976), pemilik perusahaan dapat mengeluarkan biaya pengawasan terhadap kinerja dan perilaku pengelola yang disebut agency cost. Untuk meminimalisir biaya yang dikeluarkan oleh pemilik perusahaan maka dapat dengan meningkatkan kepemilikan manajerial terhadap perusahaan. Dengan adanya kepemilikan manajerial maka setiap kebijakan di dalam perusahaan akan dipilih dengan teliti agar tidak merugikan pemilik perusahaan.

Kepemilikan manajerial berpengaruh negatif terhadap perataan laba karena dalam aktivitas perusahaan yang memiliki kepemilikan manajerial tentu akan berbeda dengan perusahaan yang tidak memiliki kepemilikan manajerial. Adanya kepemilikan manajerial akan meningkatkan kontrol dalam perusahaan karena kepemilikan manajerial dapat membentuk hubungan yang selaras dan sikron sebagai manajer dan pemilik perusahaan. Dengan adanya kepemilikan manajerial yang cukup besar oleh manajemen dan pemikiran untuk mengembangkan perusahaan oleh manajemen, maka dapat meminimalisir tindakan perataan laba.

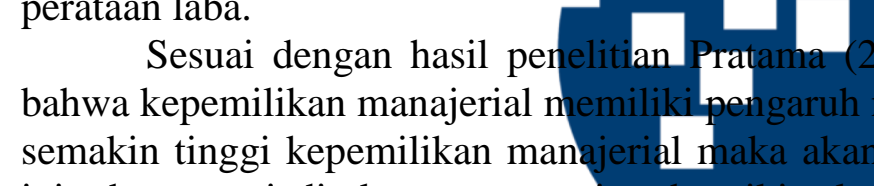

ini dapat terjadi karena manajer berpik mementingkan pengembangan perusahaan penelitian sebelumnya maka, kepemilikan saham perusahaan oleh manajemen akan mampu meminimalisir praktik perataan laba. Berbeda dengan hasil yang dilakukan oleh Nazira dan Ariani (2016) yang menyatakan bahwa kepemilikan nanajerial berpengaruh terhadap perataan laba. Dan hasil penelitian yang sama juga diperoleh oleh Nur Farida (2010) yang menyatakan bahwa kepemilikan manajerial berpengaruh terhadap perataan laba.

H4: Kepemilikan manajerial berpengarub terbadap perataan laba pada perusahaan property dan real estate yang terdaftar di BEI tahun 2014-2017.

H9: Kepemilikan manajerial berpengaruh terhadap perataan laba pada perusahaan property dan real estate yang terdaftar di KLSE tahun 2014-2017.

Penelitian yang dilakukan oleh Kustono (2009) tidak berhasil membuktikan bahwa Dividend payout ratio berpengaruh terhadap perataan laba. Penelitian yang dilakukan oleh Budiasih (2009) yang menyatakan bahwa Dividend payout ratio berpengaruh positif terhadap praktik perataan laba. Dalam teori keagenan manajer adalah pihak yang diberi wewenang untuk menjalankan perusahaan sesuai dengan keinginan dan untuk kepentingan pemegang saham. Keinginan dari pemegang saham adalah perusahaan mempunyai kinerja baik yang dapat tercermin dari laba yang dihasilkan setiap periodenya, kestabilan laba menunjukkan kestabilan kinerja dan mampu menghadapi resiko yang ada. Hal tersebut dapat memungkinkan manajemen untuk melakukan perataan laba. Menurut Nazira dan Ariani (2016) bahwa Dividend payout ratio berpengaruh positif terhadap perataan laba dan menurut Purwanto (2005) menyimpulkan bahwa Dividend payout ratio sangat mempengaruh perilaku 
perataan laba. Begitu juga dengan penelitian Sindi (2011) yang menunjukan bahwa Dividend payout ratio juga mempengaruhi perataan laba.

\section{H5: Dividend payout ratio berpengaruh terhadap perataan laba pada perusahaan property dan real estate yang terdaftar di BEI tahun 2014-2017.}

H10: Dividend payout ratio berpengaruh terhadap perataan laba pada perusahaan property dan real estate yang terdaftar di KLSE tahun 2014-2017.

\section{Metode Penelitian}

Populasi yang digunakan sebagai bahan penelitian ini adalah semua perusahaan sektor Property dan Real estate di Bursa Efek Indonesia (BEI) dan Bursa Malaysia (KLSE) Periode 2014-2017.

Teknik sampel yang digunakan dalam penelitian ini adalah purposive sampling. Purposive sampling adalah teknik penentuan sampel dengan pertimbangan tertentu (Sugiyono, 2014:126). Adapun kriteria-kriteria yang telah ditentukan dalam pemilihan sampel adalah:

a. Perusahaan sektor Property dan Real estate di Bursa Efek Indonesia (BEI) dan Bursa Malaysia (KLSE) Periode 2014

b. Perusahaan Property dan Real Estate yang memiliki laporan keuangan secara berturut-turut mulai tahun 2014-2017 di Bursa Efek Indonesia (BEI) dan Bursa Malaysia (KLSE) c. Perusahaan Property dan-Real-Estate yang menggunakan satuan mata uang Rupiah
(Rp) dan Ringgit (Rm).

d. Perusahaan Property dan Real Estat 2017 di Bursa Efek Indonesia (BEI) dan Bursa Malaysia (KLSE).

e. Perusahaan Property dan Real Estate yang membuat laporan keuangan per tanggal 31 Desember tahun 2014 -2017 di-Bursa Efek Indonesia (BEI) dan Bursa Malaysia (KLSE).

f. Perusahaan Property dan Real Estate yang memiliki kelengkapan data dalam mengisi angka variabel penelitian.

Teknik Analisis Data yang digunakan/yatu Analisis Regresi Logistik. Dalam pengujian hipotesis menggunakan penguja Perstal, dalam penelitian ini juga menggunakan Wald Statistic yaitu untuk mengetahu apakah variabel independen berpengaruh terhadap variabel dependen yaitu perataan laba adapun variabel independen nya adalah Dewan Komisaris Independen, Komite Audit, Kualitas Audit, Kepemilikan Manajerial Dan Dividend Payout Ratio.

Dalam penelitian ini untuk memisahkan perusahaan yang melakukan praktik perataan laba dan tidak, peneliti menggunakan indeks Eckel. Dalam penelitian ini variabel dependen menggunakan variabel dummy dengan menggunakan kode 1 untuk perusahaan yang melakukan praktik perataan laba dan 0 untuk perusahaan yang tidak melakukan perataan laba. Indeks Eckel (1981) dalam Butar-butar dan Sudarsi (2012) menggunakan Coefficient Variation (CV) variabel laba setelah pajak dan variabel penjualan bersih. Indeks perataan laba dapat dihitung sebagai berikut;

$$
\text { Indeks Perataan Laba }=\frac{C V \Delta E A T}{C V \Delta S}
$$


Keterangan:
a. $\triangle E A T$
: Perubahan laba dalam satu periode.
b. $\Delta S$
: Perubahan penjualan dalam satu periode.
c. $\mathrm{CV}$
: Koefisien variasi dari variabel.

$$
\mathrm{CV}=\sqrt{\frac{\sum\left(\Delta x-\overline{\Delta x)^{2}}\right.}{n-1}}: \overline{\Delta X}
$$

Keterangan :
a. $\Delta X$
: Perubahan laba atau penjualan antara tahun $\mathrm{n}$ dan $\mathrm{n}-1$.
b. $\overline{\Delta X}$
: Rerata perubahan laba atau penjualan antara tahun $\mathrm{n}$ dan $\mathrm{n}-1$.
c. $\mathrm{n}$
: Banyaknya tahun yang diamati

Variabel independen pada penelitian ini adalah dewan komisaris independen, komite audit, kualitas audit, kapemilkikan manajerial dan dividend payout ratio.

Dewan komisaris independen adalah anggota komisaris yang berasal dari luar perusahaan (tidak memiliki hubungan afiliasi dengan perusahan). Menurut Widjaja (2009:82) pengukuran dewan komisaris independen adalah sebagai berikut:

Keterangan:

DKI: Dewan komisaris independen

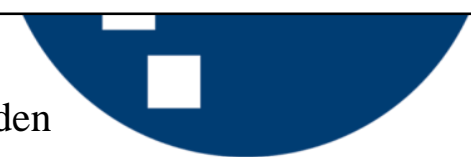

Pada umumnya komite audit itu terdiri dari tiga atau lima kadang tujuh orang yang bukan bagian dari manajemen perusahaan. Tujuan dibentuknya komite audit yaitu untuk menjadi penengah antara audito dan manajemen perusahaan apabila terjadi perselisihan. Pengukuran komite audit dilakukan dengan cara numeral, yaitu dilihat dari jumlah nominal dari anggota komite audit.

\section{Komite Audit =Jumlah anggota Komite Audit}

Menurut Marpaung dan Latrini (2014) Kualitas audit diproksikan dengan ukuran KAP (KAP The big- 4 dan KAP Non The big-4). Dalam penelitian ini, kualitas audit di ukur dengan ukuran KAP. Dalam mengukur ukuran KAP merupakan variabel dummy. Perusahaan yang menggunakan KAP The big- 4 diberi kode 1, sedangkan perusahaan yang menggunakan KAP Non The big- 4 diberi kode 0.

Pada faktor mengenai kepemilikan manajerial, varial kepemilikan manajerial diukur dari jumlah persentase kepemilikan saham dari manajemen perusahaan yang meliputi manajer maupun dewan direksi. Indicator yang digunakan untuk mengukur kepemilikan manajerial adalah persentase jumlah saham yang dimiliki pihak manajemen dari seluruh modal perusahaan yang beredar yang dimiliki (Aji dan Mita, 2010). Ada pun dalam pengukuran dari kepemilikan manajerial dapat dirumuskan sebagai berikut: 


$$
\text { Kepemilikan Manajerial }=\frac{\begin{array}{c}
\text { Jumlah Saham Yang Dimiliki } \\
\text { Pihak Manajemen }
\end{array}}{\text { Jumlah Saham Beredar }} \times 100 \%
$$

Dividend Payout Ratio diukur dengan menggunakan perbandingan antara dividend per share dengan earning per share. Variabel ini membandingkan dividen dengan laba bersih perusahaan. Variabel ini diukur dengan cara melakukan pembagian antara dividend per share (DPS): yaitu jumlah dividen yang dibagikan ke pemegang saham (investor) per lembarnya, dengan earning per share (EPS): yaitu jumlah laba bersih perusahaan per lembar saham.

$$
\text { DPR }=\frac{\text { DPS }}{E P S}
$$

Keterangan :

DPR :Dividend payout ratio

DPS :Dividend per share

EPS :Earnings per share

Variabel kontrol dalam diukur dengan cara me-logka mengendalikan pengaruh penga

\section{Ukuran perusahaan $=$ Ln Total Aktiva}

\section{HASIL DAN PEMBAHASAN}

\subsection{Populasi dan sampel}

Objek penelitian ini adallah penisahaan yang bergerak di sektor Property dan Real Estate yang terdaftar di Bursa Efek Indonesia (BEI) dan perusahaan yang terdaftar di Bursa Malaysia (KLSE) dengan periode pengamatan yang diambil adalah tahun 2014 - 2017. Populasi penelitian diambil dari data yang terdaftar di Bursa Efek Indonesia (BEI) dan Bursa Malaysia (KLSE). Dalam melakukan pemilihan sampel, peneliti menggunakan teknik purposive sampling karena adanya kriteria tertentu dalam menentukan sampel yang digunakan.

Berikut tabel yang dapat memberikan gambaran lebih jelas atas pemilihan sampel yang akan digunakan dalam penelitian ini

Tabel 1. Jumlah Sampel Indonesia dan Malaysia yang Memenuhi Kriteria

\begin{tabular}{llcc}
\hline & \multicolumn{1}{c}{ KRITERIA } & JUMLAH PERUSAHAAN \\
\hline NO. & \multicolumn{1}{c}{ BEI } & KLSE \\
\hline 1 & $\begin{array}{l}\text { Perusahaan Property dan Real Estate yang terdaftar di } \\
\text { Bursa Efek Indonesia (BEI) periode 2014-2017 }\end{array}$ & $\mathbf{4 8}$ & $\mathbf{1 0 1}$ \\
\hline 2 & $\begin{array}{l}\text { Perusahaan Property dan Real Estate yang tidak } \\
\text { memiliki laporan keuangan secara berturut-turut } \\
\text { mulai tahun 2014-2017 }\end{array}$ & $\mathbf{- 5}$ & $\mathbf{- 1 1}$ \\
\hline 3 & $\begin{array}{l}\text { Perusahaan Property dan Real Estate yang tidak } \\
\text { menggunakan satuan mata uang Rupiah (Rp) dan } \\
\text { Ringgit (Rm) }\end{array}$ & $\mathbf{0}$ & $\mathbf{0}$ \\
\hline 4 & Perusahaan Property dan Real Estate yang mengalami & & \\
\hline
\end{tabular}




\begin{tabular}{|c|c|c|c|}
\hline & kerugian tahun 2014-2017 & -8 & -24 \\
\hline 5 & $\begin{array}{l}\text { Perusahaan Property dan Real Estate yang tidak } \\
\text { membuat laporan keuangan per tanggal } 31 \text { Desember } \\
\text { tahun } 2014-2017\end{array}$ & $\mathbf{0}$ & -46 \\
\hline 6. & $\begin{array}{l}\text { Perusahaan Property dan Real Estate yang tidak } \\
\text { memiliki kelengkapan data dalam mengisi angka } \\
\text { variabel penelitian }\end{array}$ & -27 & -2 \\
\hline & Jumlah Sampel Perusahaan & 8 & 18 \\
\hline & Periode Penelitian & 4 Tahun & 4 Tahun \\
\hline & Jumlah Sampel Penelitian & 32 & 72 \\
\hline
\end{tabular}

Sumber : Diperoleh dari olahan sampel (2018)

\subsection{Analisis Statistik Deskriptif}

Tabel 2. Hasil Uji Deskriptif Statistik Indonesia

\begin{tabular}{llllllll}
\hline & $\mathrm{Y} 1$ & $\mathrm{X} 1$ & $\mathrm{X} 2$ & $\mathrm{X} 3$ & $\mathrm{X} 4$ & $\mathrm{X} 5$ & $\mathrm{C} 1$ \\
\hline Mean & 0.500000 & 0.3546888 & 3.000000 & 0.500000 & 0.018952 & 0.356549 & 29.22315 \\
\hline Median & 0.500000 & 0.3300000 & 3.000000 & 0.500000 & 0.001398 & 0.156302 & 29.46092 \\
\hline Maximum & 1.000000 & 0.6700000 & 4.000000 & 1.000000 & 0.269165 & 4.829672 & 30.99105 \\
\hline Minimum & 0.000000 & 0.1700000 & 2.000000 & 0.000000 & 0.000000 & 0.020572 & 26.71921 \\
\hline Srd. Dev & 0.508001 & 0.126898 & 0.508001 & 0.508001 & 0.048079 & 0.855821 & 1.303293 \\
\hline Skewness & 0.000000 & 1.195194 & $-6.25 \mathrm{E}-17$ & 0.000000 & 4.599253 & 4.742541 & -0.498645 \\
\hline Kurtosis & 1.000000 & 4.524778 & 4.000000 & 1.000000 & 24.44716 & 24.96532 & 2.240526 \\
\hline Jarque & 5.333333 & 10.71854 & 1.333333 & 5.333333 & 726.1244 & 768.2563 & 2.095184 \\
Bera & & & & & & & \\
\hline Probability & 0.069483 & 0.0047004 & 0.513417 & 0.069483 & 0.000000 & 0.000000 & 0.350781 \\
\hline Sum & 16.00000 & 10.71854 & 96.00000 & 16.00000 & 0.606468 & 11.40955 & 935.1407 \\
\hline Sum Sq.Dev & 8.000000 & 0.499197 & 8.000000 & 8.000000 & 0.071659 & 22.70534 & 52.65576 \\
\hline Observation & 32 & 32 & 32 & 32 & 32 & 32 & 32 \\
\hline
\end{tabular}

Sumber : Output dari eviews Versi 10

Variabel Dewan Komisaris Independen memiliki nifar paling tinggi yaitu perusahaan Pakuwon Jati Tbk dengan kode saham PWoN/Perusahaan dengan nilai Dewan komisaris terendah yaitu sebesar 0.170000 yang dimiliki dleh perusahaan Intiland Development Tbk dengan kode saham DILD.

Variabel Komite Audit memiliki nilai paling tinggi yaitu perusahaan Metropolitan Kentjana Tbk dengan kode saham MKPI . Perusahaan dengan nilai Komite audit terendah yaitu sebesar 2.000000 yang dimiliki oleh perusahaan Roda Vivatex Tbk dengan kode saham RDTX.

Variabel Kualitas Audit memiliki rata - rata sebesar 0.500000 dengan nilai Standar Deviasi lebih besar dari nilai rata - rata yaitu sebesar 0.508001 dan nilai maximum sebesar 1.000000 menunjukkan bahwa nilai dari kualitas audit paling tinggi dan nilai minimum sebesar 0.000000 yaitu Perusahaan dengan nilai Komite audit terendah.

Variabel Kepemilikan Manajerial memiliki nilai paling tinggi yaitu perusahaan Pudjiati Prestige Tbk dengan kode saham PUDP . Perusahaan dengan nilai Komite audit terendah yaitu sebesar 0.000000 yang dimiliki oleh perusahaan Intiland Development Tbk kode saham DILD.

Variabel Dividend Payout Ratio memiliki nilai maximum sebesar 4.829672 menunjukkan bahwa nilai dari dividen payout ratio paling tinggi yaitu perusahaan Greenwood Sejahtera Tbk dengan kode saham GWSA . Perusahaan dengan nilai dividen payout ratio 
terendah yaitu sebesar 0.020572 yang dimiliki oleh perusahaan Agung Podomoro Tbkkode saham APLN.

Variabel Ukuran Perusahaan memiliki nilai maximum sebesar 30.99105 menunjukkan bahwa nilai dari Ukuran Perusahaan paling tinggi. Dan terdapat nilai terendah yaitu sebesar 0.050191 .

Tabel 3. Hasil uji Deskriptif Statistik Malaysia

\begin{tabular}{llllllll}
\hline & $\mathrm{Y} 2$ & $\mathrm{X} 6$ & $\mathrm{X} 7$ & $\mathrm{X} 8$ & $\mathrm{X} 9$ & $\mathrm{X} 10$ & $\mathrm{C} 2$ \\
\hline Mean & 0.541667 & 0.4455556 & 3.166667 & 0.555556 & 0.422936 & 0.528886 & 20.81551 \\
\hline Median & 1.000000 & 0.4300000 & 3.0000000 & 1.000000 & 0.287938 & 0.230677 & 20.95788 \\
\hline Maximum & 1.000000 & 0.8600000 & 5.0000000 & 1.000000 & 2.447876 & 5.652174 & 23.53237 \\
\hline Minimum & 0.000000 & 0.2000000 & 3.000000 & 0.000000 & $2.20 \mathrm{E}-05$ & 0.050191 & 18.34836 \\
\hline Srd. Dev & 0.501757 & 0.127808 & 0.444053 & 0.500391 & 0.560792 & 1.107109 & 1.371800 \\
\hline Skewness & -0.167248 & 0.820294 & 2.699746 & -0.223607 & 1.848116 & 3.877146 & -0.127095 \\
\hline Kurtosis & 1.027972 & 3.844353 & 9.734694 & 1.050000 & 6.162254 & 16.87653 & 1.823446 \\
\hline Jarque & -12.00235 & 10.21339 & 223.5319 & 12.002469 & 70.98593 & 758.0613 & 4.346675
\end{tabular}

Bera

\begin{tabular}{llllllll}
\hline Probability & 0.002476 & 0.006056 & 0.000000 & 0.002469 & 0.000000 & 0.000000 & 0.113797 \\
\hline Sum & 39.00000 & 32.08000 & 228.0000 & 40.00000 & 30.45137 & 38.07981 & 1298.716 \\
\hline Sum Sq.Dev & 17.87500 & 1.159778 & 14.00000 & 17.77778 & 22.32861 & 87.02406 & 133.6102 \\
\hline Observation & 72 & 72 & 72 & 72 & 72 & 72 & 72 \\
\hline
\end{tabular}

Variabel Dewan Komisaris Independen memiliki nlai maximum sebesar 0.860000 menunjukkan bahwa nilai dari dewan komisaris independen paling tinggi yaitu perusahaan Paramount Corporation Berhad. Perusahaan dengan nilaj Dewan komisaris terendah yaitu sebesar 0.200000 yang dimiliki oleh perusah

Variabel Komite Audit memiliki nilai maxmum sebesar 5.000000 menunjukkan bahwa nilai dari komite audit paling tinggi yaitu perusahaan Mah Sing Group Berhad. Perusahaan dengan nilai Komite audit terendah yaitu sebesar 3.000000 yang dimiliki oleh perusahaan farlim group (malaysia) bh

Variabel kualitas audit memilik rata - rata sebesar 0.555556 dengan nilai Standar Deviasi lebih kecil dari nilai rata - rata yaitu sebesar 0.500391 dan nilai maximum sebesar 1.000000 menunjukkan bahwa nilai dari kualitas audit paling tinggi dan nilai minimum sebesar 0.000000 yaitu Perusahaan dengan nilai Komite audit terendah.

Variabel Kepemilikan Manajerial memiliki rata - rata sebesar 0.4229362 dengan nilai Std. Deviasi lebih besar dari nilai rata - rata yaitu sebesar 0.560792 dan nilai maximum sebesar 2.447876 menunjukkan bahwa nilai dari kepemilikan manajerial paling tinggi yaitu perusahaan Gromutual Berhad . Perusahaan dengan nilai Kepemilikan manajerial terendah yaitu sebesar 0.000022 yang dimiliki oleh perusahaan Uem Sunrise Berhad.

Variabel Dividend Payout Ratio memiliki nilai maximum sebesar 5.652174 menunjukkan bahwa nilai dari dividen payout ratio paling tinggi yaitu perusahaan Uoa Development Bhd. Perusahaan dengan nilai dividen payout ratio terendah yaitu sebesar 0.050191yang dimiliki oleh perusahaan Osk Holding Berhad.

Variabel Ukuran Perusahaan memiliki nilai maximum sebesar 23.53237 menunjukkan bahwa nilai dari Ukuran Perusahaan paling tinggi. Dan terdapat nilai terendah yaitu sebesar 18.34836 . 


\subsection{Uji Asumsi Klasik}

\section{Uji Normalitas}

Uji normalitas dapat dilakukan dengan menggunakan eviews yang dilihat menggunakan uji histogram dan Jarque - Bera, jika probabilitas lebih besar dari pada alpa $(\alpha=$ 0,05) maka asumsi normalitas terpenuhi (Ghozali, 2013).

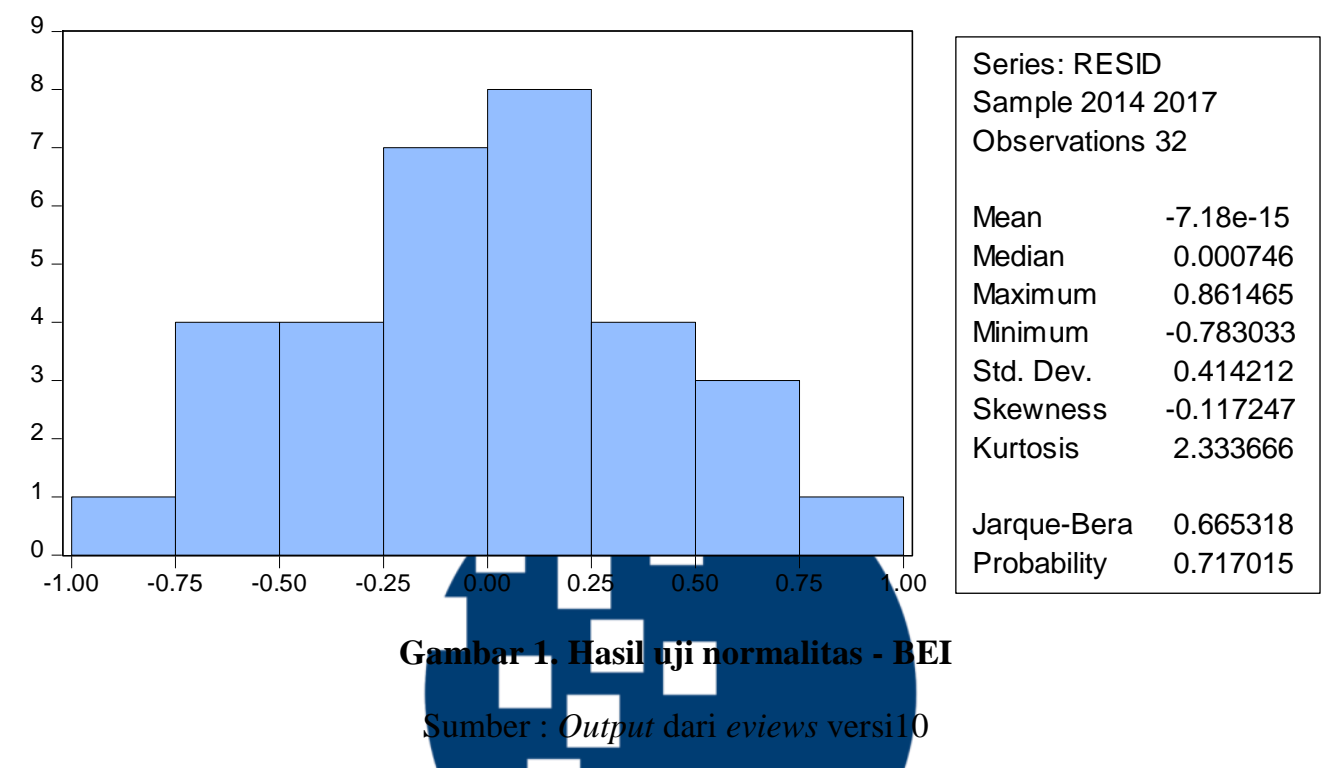

Berdasarkan Gambar 1 untuk perusahaan sektor properti dan real estate Indonesia, nilai Jarque-Bera sebesar 0.665318, nilai Jarque-Bera $\left\langle\psi^{2}\right.$ atau lebih kecil dari 2 , maka data berdistribusi normal. Lalu nilai p-value sebesar 0.717015 dimana > 0,05 sehingga nilai probabilitas didapat lebih besar dari 0.05 sehingga hipotesis berdistribusi normal.

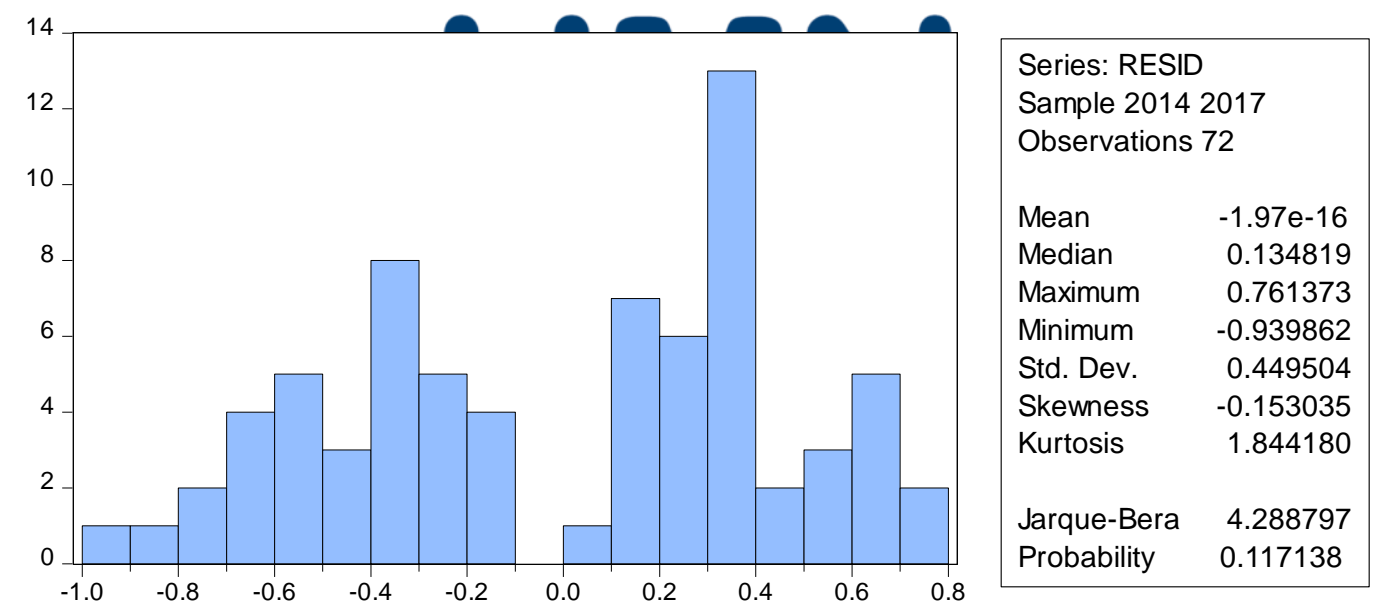

Gambar 2. Hasil uji normalitas - KLSE

Sumber : Output dari eviews versi10

Berdasarkan hasil dari Gambar 2 untuk perusahaan sektor property dan real estate Malaysia, nilai Jarque-Bera sebesar 4.288797, nilai Jarque-Bera $>\mathrm{X}^{2}$ atau lebih besar dari 2, 
maka data berdistribusi tidak normal. Lalu nilai p-value sebesar 0.117138 dimana $>0,05$ sehingga nilai probabilitas berdistribusi normal yang berarti data berdistribusi normal.

\section{Uji Multikolinearitas}

Uji Multikolinieritas adalah kondisi adanya hubungan linier antar variabel independen, dikarenakan melibatkan beberapa variabel independen. Berikut pada tabel 4 hasil uji multikolinearitas dari nilai matrix korelasi untuk perusahaan sektor property dan real estate Indonesia dan perusahaan sektor property dan real estate Malaysia sebagai berikut:

Tabel 4. Hasil Uji Multikolinearitas - BEI dan KLSE

\begin{tabular}{|c|c|c|c|c|c|c|}
\hline \multicolumn{7}{|c|}{ Hasil uji multikolinearitas BEI } \\
\hline & $\mathrm{Y} 1$ & $\mathrm{X} 1$ & $\mathrm{X} 2$ & $\mathrm{X} 3$ & $\mathrm{X} 4$ & $\mathrm{X} 5$ \\
\hline $\mathrm{Y} 1$ & 1.000000 & -0.407828 & 0.000000 & -0.500000 & 0.273143 & -0.210592 \\
\hline $\mathrm{X} 1$ & -0.407828 & 1.000000 & -0.035028 & 0.552944 & -0.085347 & -0.076995 \\
\hline $\mathrm{X} 2$ & 0.000000 & -0.035028 & 1.000000 & 0.000000 & 0.067374 & 0.062024 \\
\hline $\mathrm{X} 3$ & -0.500000 & 0.552944 & 0.000000 & 1.000000 & -0.377231 & 0.188960 \\
\hline $\mathrm{X} 4$ & 0.273143 & -0.085347 & & -0.377231 & 1.000000 & -0.059995 \\
\hline $\mathrm{X} 5$ & -0.210592 & -0.076 & & 960 & -0.059995 & 1.000000 \\
\hline \multicolumn{7}{|c|}{ Hasil uji multikolinearitas KLSE } \\
\hline & $\mathrm{Y} 2$ & $\mathrm{X} 6$ & $\mathrm{X}$ & $\mathrm{X} 8$ & $\mathrm{X} 9$ & $\mathrm{X} 10$ \\
\hline Y2 & 1.000000 & 0.1588 & 0.03160 & -0.1 & 0.180627 & 0.088220 \\
\hline $\mathrm{X} 6$ & 0.158865 & 1.00 & -0.11333 & 0.171289 & -0.304768 & -0.083539 \\
\hline $\mathrm{X} 7$ & -0.031607 & -0.1 & & 0.211289 & -0.085390 & -0.079456 \\
\hline $\mathrm{X} 8$ & -0.149592 & 0.17 & 0.211289 & 1.000000 & -0.200736 & -0.260618 \\
\hline $\mathrm{X} 9$ & 0.180627 & -0.30 & 0.085390 & -0.200736 & 1.000000 & -0.140901 \\
\hline $\mathrm{X} 10$ & 0.088220 & -0.0835 & 0.079456 & 0618 & -0.140901 & 1.000000 \\
\hline
\end{tabular}

Berdasarkan tabel 4 hasil uji multikolinearitas untuk perusahaan manufaktur Indonesia tergambar tidak adanya nilai matrik korelasi yang diatas atau > 0,90. Menurut Ghozali (2013:83), jika matrik korelas tidak ada nilai >0.90 maka tidak terjadi multikolinearitas dalam model. Sedangkan hasil uji multikolinearitas untuk perusahaan manufaktur Malaysia tergambar tidak adanya nilai matrik korelasi yang diatas atau > 0,90. Jadi dapat disimpulkan bahwa data perusahaan sektor property dan real estate Malaysia tidak memiliki hubungan linier antar variabel.

\section{Uji Heteroskedastisitas}

Untuk mendeteksi adanya heteroskedastisitas dalam penelitian salah satunya adalah menggunakan cara dalam prosedur statistik dengan uji White. Berikut hasil uji heteroskedastisitas dengan uji White pada perusahaan sektor property dan real estate Indonesia dan perusahaan sektor property dan real estate Malaysia pada tabel 5 : 
Tabel 5. Hasil Uji Heteroskedastisitas - BEI dan KLSE

\begin{tabular}{llll}
\hline Hasil Uji Heteroskedastisitas - BEI & & \\
\hline F-Statistic & 1.980329 & Prob. F $(25,6)$ & 0.2014 \\
\hline Obs*R- squared & 28.54105 & $\begin{array}{l}\text { Prob.Chi-Squared } \\
(25)\end{array}$ & 0.2836 \\
\hline Scaled explained SS & 10.01654 & $\begin{array}{l}\text { Prob.Chi-Squared } \\
(25)\end{array}$ & 0.9966 \\
\hline Hasil Uji Heteroskedastisitas - KLSE & & 0.3643 \\
\hline F-Statistic & 1.116652 & Prob. F (26,45) & 0.3470 \\
\hline Obs*R- squared & 28.23570 & $\begin{array}{l}\text { Prob.Chi-Squared } \\
(26)\end{array}$ & 0.9987 \\
\hline Scaled explained SS & 9.527446 & $\begin{array}{l}\text { Prob.Chi-Squared } \\
(26\end{array}$ & \\
\hline & & &
\end{tabular}

Sumber : Output dari eviews versi10

Berdasarkan tabel 5 hasil uji heteroskedastisitas pada perusahaan sektor property dan real estate di Indonesia dapat dilihat nilai Obs*R-squared adalah 28.54105, dan probabilitasnya adalah 0.2836 lebih besar dari $\alpha=5 \%$. Hal ini mengindikasikan bahwa data penelitian ini tidak mengandung heteroskedastisitas. Sedangkan hasil uji heteroskedastisitas pada perusahaan sektor propertty dan real estate di Malaysia dapat dilihat nilai Obs*Rsquared adalah 28.23570, dan probabilitasnya adalah 0.3470 lebih besar dari $\alpha=5 \%$. Maka dapat disimpulkan bahwa data penelitian terbebas dari masalah heteroskedastisitas

\section{Uji Autokorelasi}

Pada penelitian ini, penulis menggunakan metode Breusch-Godfrey untuk mengetahui apakah adanya terjadi Autokorelasi pada data observasi. Berikut hasil uji autokorelasi pada perusahaan sektor property dan real estate di Indonesia dan Malaysia:

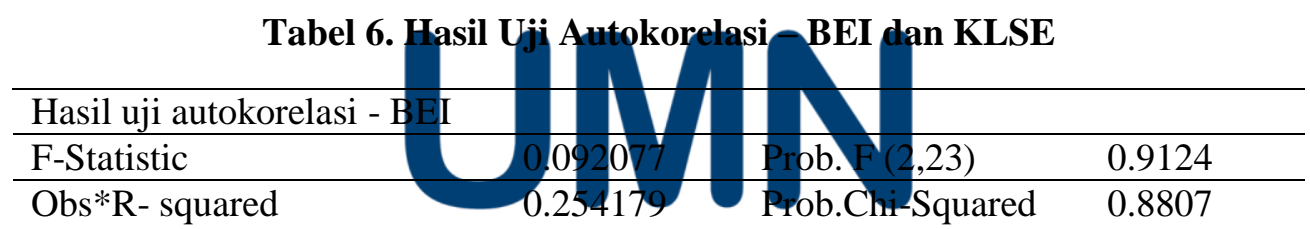

(2)

\begin{tabular}{llll}
\hline Hasil uji autokorelasi - KLSE & & & \\
\hline F-Statistic & 1.947622 & Prob. F $(2,63)$ & 0.1511 \\
\hline Obs*R- squared & 4.192489 & $\begin{array}{l}\text { Prob.Chi-Squared } \\
(2)\end{array}$ & 0.1229 \\
& & &
\end{tabular}

Sumber : Output dari eviews versi10

Berdasarkan tabel 6 hasil uji autokorelasi perusahaan sektor property dan real estate di Indonesia memiliki nilai probability> 5\% (0.8807> 0,05) dan hasil uji autokorelasi perusahaan sektor property dan real estate di Malaysia memiliki nilai probability> 5\% (0.1229> 0,05). Maka hal ini mengindikasikan bahwa penelitian ini tidak mengandung autokorelasi. 


\subsection{Analisis Regresi Logistik}

Analisis yang digunakan dalam penelitian ini menggunakan analisis regresi logistik binary dengan pilihan model logit (logistic regression), karena data variabel dependen penelitian ini berbentuk variabel dummy yaitu berisi kemungkinan diantara 0 dan 1 . Hasil dari pengujian regresi logistik binary pada penelitian ini ditunjukan pada tabel 7 untuk perusahaan sektor property dan real estate yang terdaftar di Bursa Efek Indonesia (BEI) dan tabel 8 untuk perusahaan sektor property dan real estate yang terdaftar di Bursa Malaysia sebagai berikut :

Tabel 7. Hasil Analisa Regresi Logistik - BEI

\begin{tabular}{|c|c|c|c|}
\hline Variabel & Koefisien & Z-Statistik & Prob \\
\hline $\mathrm{X} 1$ & -9.024162 & -1.277841 & 0.2013 \\
\hline $\mathrm{X} 2$ & 0.144916 & 0.144232 & 0.8853 \\
\hline X3 & -0.376191 & -0.235673 & 0.8137 \\
\hline $\mathrm{X} 4$ & 23.16593 & 0.464148 & 0.6425 \\
\hline $\mathrm{X} 5$ & -3.030234 & -0.685184 & 0.4932 \\
\hline $\mathrm{C}$ & 8.618322 & 0.566370 & 0.5711 \\
\hline $\mathbf{N}$ & & & \\
\hline McFadde & & 218 & \\
\hline LR Statis & & 12.96169 & \\
\hline Prob (LR & & 0.043648 & \\
\hline
\end{tabular}

$\operatorname{Ln}(\mathrm{Y} 1 / \mathrm{Y} 1-1)_{\text {indo }}=8.618322--9.024162 \mathrm{X} 1-0.144916 \mathrm{X} 2--0.376191 \mathrm{X} 3+23.16593 \mathrm{X} 4$ $--3.030234 \times 5+\varepsilon$

\begin{tabular}{|c|c|c|c|}
\hline Variabel & & & Prob \\
\hline X6 & 4.428738 & 644 & 0.0567 \\
\hline $\mathrm{X} 7$ & 0.269594 & 0.446978 & 0.6549 \\
\hline $\mathrm{X} 8$ & -0.908302 & -1.521329 & 0.1282 \\
\hline X9 & 1.605851 & 2.371765 & 0.0177 \\
\hline $\mathrm{X} 10$ & 0.200323 & 0.763148 & 0.4454 \\
\hline $\mathrm{C}$ & -13.00739 & -2.490332 & 0.0128 \\
\hline $\mathbf{N}$ & & 72 & \\
\hline McFadden R-Square & & 0.142500 & \\
\hline LR Statistic & & 14.15204 & \\
\hline $\begin{array}{l}\text { Prob } \\
\text { Statistic })\end{array}$ & & 0.027983 & \\
\hline
\end{tabular}

Sumber : Output dari eviews versi10

Berdasarkan hasil pengujian logistik yang dilakukan pada tabel 8 untuk perusahaan sektor property dan real estae yang terdaftar di Bursa Malaysia (KLSE), maka dapat diperoleh persamaan sebagai berikut : 
$\operatorname{Ln}(\mathrm{Y} 1 / \mathrm{Y} 1-1)_{\text {Mly }}=-13.00739-4.428738 \mathrm{X} 6-0.269594 \mathrm{X} 7--0.908302 \mathrm{X} 8+1.605851 \mathrm{X} 9$ $-0.200323 \times 10+\varepsilon$

\section{Menilai kelayakan model Regresi}

Penelitian ini melakukan pengujian terhadap kelayakan model regresi logistik binary yang telah ditetapkan. Hasil uji dapat dilihat pada tabel 9 untuk perusahaan sektor property dan real estate Indonesia yang terdaftar di Bursa Efek Indonesia (BEI) dan Bursa Malaysia (KLSE) sebagai berikut :

\section{Tabel 9. Hosmer and Lemeshow's Goodness of Fit Test - BEI dan KLSE}

\begin{tabular}{lccc}
\hline \multicolumn{4}{l}{ Hasil uji Hosmer and Lemeshow - BEI } \\
\hline H-L Statistic & 7.2023 & Prob. Chi-Sq(8) & 0.5150 \\
\hline Hasil uji Hosmer and Lemeshow - KLSE & \\
\hline H-L Statistic & 5.1079 & Prob. Chi-Sq(8) & 0.7460 \\
\hline \multicolumn{4}{c}{ Sumber : Output dari eviews versi10 } \\
\hline
\end{tabular}

Dari hasil uji pada tabel 9 menunjukkan untuk data BEI nilai dari statistik Hosmer and Lemeshow's sebesar 7.2023 dan untuk nilai Chi-Square dari hasil uji Hosmer and Lemeshow's Goodness of Fit Test adalah sebesar 0.5150. Hal ini menunjukkan bahwa model regresi binary layak dipakai untuk analisis selanjutnya Dari hasil uji pada tabel 9 menunjukkan untuk data KLSE nilai dari-statistik Hosmer and Lemeshow's sebesar 5.1079 dan untuk nilai Chi-Square dari hasi uji Hosmer and Lemeshow's Goodness of Fit Test adalah sebesar 0.7460 . Nilai probabilitas Chi-Square untul perusahaan sektor property dan real estate Malaysia sebesar 0.7460 yaitulebih besar dari nuai 0.05 , maka $\mathrm{H}_{0}$ diterima. Hal ini mengartikan bahwa model ini dapat memberikan prediksi nilai observasi yang sesuai.

\section{Uji Omnibus}

Model logistik dapat dinilai dengan menggunakan likelihod ratio (LR) statistic. Model ini dilakukan untuk mengetahui apakah yariabel independen secara bersama-sama berpengaruh signifikan terhadap variabel dependen. Tabel 10 mengganbarkan hasil uji omnibus untuk perusahaan sektor property dan real estate Indonesia dan Malaysia sebagai berikut:

Tabel 10 Hasil Uji Omnibus - BEI dan KLSE

\begin{tabular}{|c|c|}
\hline Hasil uji Omnibus - BEI & \\
\hline Prob(LR statistic) & 0.043648 \\
\hline Hasil uji Omnibus - KLSE & \\
\hline Prob(LR statistic) & 0.027983 \\
\hline
\end{tabular}

Dapat dilihat untuk data BEI pada item prob>chi2 menunjukkan angka 0.043648, dimana nilai ini lebih kecil bila dibandingkan dengan tingkat signifikansi uji sebesar 0.05 . Dengan menggunakan tingkat keyakinan sebesar 95\% maka variabel-variabel independen pada perusahaan property dan real estate di indonesia secara simultan berpengaruh terhadap variabel dependen. Untuk data KLSE pada item prob>chi2 menunjukkan angka 0.027983, dimana nilai ini lebih kecil bila dibandingkan dengan tingkat signifikansi uji sebesar 0.05 , maka variabel-variabel independen pada perusahaan property dan real estate di Malaysia secara simultan berpengaruh terhadap variabel dependen. 
Uji Nagelker R Square

Hasil uji koefisien determinasi McFadden dapat dilihat pada tabel 11 untuk perusahaan sektor property dan real estate Indonesia dan Malaysia sebagai berikut:

Tabel 11. Hasil Nagelker R Square - BEI dan KLSE

\begin{tabular}{lc}
\hline \multicolumn{3}{l}{ Hasil uji Nagelker - BEI } \\
\hline McFadden R-squared & 0.292184 \\
\hline \multicolumn{3}{l}{ Hasil uji Nagelker - KLSE } \\
\hline \multicolumn{2}{l}{ McFadden R-squared 0.142500} \\
\hline \multicolumn{2}{l}{ Sumber : Output dari eviews versi10 }
\end{tabular}

Berdasarkan tabel 11 hasil uji koefisien determinasi pada perusahaan sektor property dan real estate yang terdaftar di Bursa Efek Indonesia (BEI) menunjukan hasil uji koefisien determinasi dengan menghasilkan nilai McFadden R-Squared sebesar 0.292184 atau sekitar $29,22 \%$ variasi yang terjadi pada $\mathrm{Y}$ dapat dijelaskan oleh variabel independen dalam penelitian ini, sedangkan sisanya dijelaskan-oleh variabel lain diluar dari model ini. Sedangkan untuk data Malaysia menunjukkan hasil uji koefisien determinasi dengan menghasilkan nilai McFadden R-Squared_sebesar 0.142500 atau sekitar 14,25\% variasi yang terjadi pada $\mathrm{Y}$ dapat dijelaskan oleh variabel independen dalam penelitian ini, sedangkan sisanya dijelaskan oleh variabel lain

\subsection{Uji Hipotesis}

Berikut merupakan hasil wald pada tabel 12 menunjukkan hasil hip estate yang terdaftar di Bursa Efek Indonesia (BEI) serta Bursa Malaysia (KLSE):

Tabel 12. Hasil Uji Hipotesis - BEI dan KLSE

\begin{tabular}{lll}
\hline Hasil uji hipotesis - BEI \\
\hline $\mathbf{N o}$ & Hipotesis \\
\hline $\mathbf{1}$ & X1 berpengaruh terhadap Y & Ditolak \\
\hline $\mathbf{2}$ & X2 berpengaruh terhadap Y1 & Ditolak \\
\hline $\mathbf{3}$ & X3 berpengaruh terhadap Y1 & Ditolak \\
\hline $\mathbf{4}$ & X4 berpengaruh terhadap Y1 & Ditolak \\
\hline $\mathbf{5}$ & X5 berpengaruh terhadap Y1 & Ditolak \\
\hline Hasil uji hipotesis - KLSE & \\
\hline No & Hipotesis & Hasil \\
\hline $\mathbf{1}$ & X6 berpengaruh terhadap Y2 & Ditolak \\
\hline $\mathbf{2}$ & X7 berpengaruh terhadap Y2 & Ditolak \\
\hline $\mathbf{3}$ & X8 berpengaruh terhadap Y2 & Ditolak \\
\hline $\mathbf{4}$ & X9 berpengaruh terhadap Y2 & Diterima \\
\hline $\mathbf{5}$ & X10 berpengaruh terhadap & Ditolak \\
& Y2 & \\
\hline
\end{tabular}

Sumber : Data Diolah

Berdasarkan tabel 12 menunjukkan bahwa variabel Dewan komisaris independen, komite audit, kualitas audit, kepemilikan manajerial, Dividend payout ratio dan tidak berpengaruh terhadap variabel perataan laba (Y1) pada perusahaan sektor property dan real 
estate Indonesia. Berdasarkan tabel 12 menunjukkan bahwa variabel Dewan komisaris independen, komite audit, kualitas audit dan Dividend payout ratio tidak berpengaruh terhadap perataan laba sedangkan kepemilikan manajerial berpengaruh terhadap variabel perataan laba pada perusahaan sektor property dan real estate Malaysia.

\section{PEMBAHASAN}

Hasil uji wald untuk variabel Dewan Komisaris Independen, perusahaan property dan real estate Indonesia memiliki nilai probabilitas sebesar 3.6315 dan perusahaan property dan real estate Malaysia memiliki nilai probabilitas sebesar 0.0567 . Hal ini membuktikan bahwa nilai probabilitas lebih besar dari cut off uji hipotesis sebesar 0,05 maka diterima.

Hasil penelitian ini didukung dengan penelitian terdahulu yang dilakukan Marpaung \& Latrini (2014), yang menyatakan bahwa dewan komisaris independen tidak berpengaruh secara signifikan terhadap perataan laba. Namun, terdapat penelitian yang menemukan bahwa adanya pengaruh Dewan Komisaris Independen terhadap perataan laba. Penelitian ini dilakukan oleh Nabila dan Daljono (2013), yang menyatakan bahwa Dewan komisaris independen berpengaruh terhadap praktek laba. Hasil penelitian yang sama juga dinyatakan oleh Tiswiyanti, Fitriyani dan Wiralestari (2012), bahwa Dewan Komisaris independen berpengaruh terhadap manajemen laba. Praktik perataan laba yang terjadi bukan didasarkan atas sifat dasar manusia yang akan bertindak opportunistic, yaitu mengutamakan kepentingan pribadinya dalam hal ini manajer. Pemisahan antara fungsi kepemilikan dengan fungsi pengelolaan perusahaan pada penelitian berkaitan dengan hadirnya komisaris independen menjadi sebuah skema dimana investor dalam hal ini principal mempercayakan pengelolaan sumber daya perusahaan kepada pihaklain yang berperan sebagai steward yang lebih capable dan siap. Steward tidak memiliki motivasi untuk melakukan praktik perataan laba yang merugikan principal, oleh karena itu mekanisme pengawasan melalui komisaris independen tidak mampu mempengaruhi praktik perataan laba yang terjadi.

Hasil uji wald untuk variabel komite audit, perusahaan property dan real estate Indonesia memiliki nilai probabilitas sebesar 0.8853 dan perusahaan property dan real estate Malaysia memiliki nilai probabilitas sebesar 0.6549 . Hal ini membuktikan bahwa nilai probabilitas lebih besar dari cut off uji hipotesis sebesar Q,05 maka diterima.

Hasil pengujian hipotesis menggunakan analisis regresi logistik binary dengan uji wald menunjukkan bahwa variabel Komite Audit tidak berpengaruh terhadap Perataan Laba pada perusahaan Property dan Real Estate yang terdaftar di Bursa Efek Indonesia (BEI) dan perusahaan malaysia (KLSE) tahun 2014 sampai dengan tahun 2017 dikarenakan hipotesis lebih besar dari 0.05. penelitian ini didukung oleh penelitian dari Arief Pradana, Khairunnisa \& Dewa Putra Khirisna (2016) Menemukan bahwa Komite audit tidak berpengaruh terhadap perataan laba. Dikarenakan bahwa pihak manajer tidak perlu dicurigai atau diberi pengawasan berlebihan oleh pemilik. Manajer tidak bertindak atas dasar motivasi untuk memaksimalkan nilai individu melainkan kepentingan perusahaan. Manajer berasumsi bahwa tindakannya yang berdasarkan kepentingan perusahaan pada akhirnya akan memenuhi kepentingan individunya. Sehingga keberadaan komite audit guna mengurangi perilaku opportunistic manajemen yang merugikan investor tidak berpengaruh terhadap praktik perataan laba yang terjadi.

Hasil uji wald untuk variabel kualitas audit, perusahaan property dan real estate Indonesia memiliki nilai probabilitas sebesar 0.8137 dan perusahaan property dan real estate Malaysia memiliki nilai probabilitas sebesar 0.1282 . Hal ini membuktikan bahwa nilai probabilitas lebih besar dari cut offuji hipotesis sebesar 0,05 maka diterima. 
Hasil pengujian hipotesis menggunakan analisis regresi logistik binarydengan uji wald menunjukkan bahwa variabel Kualitas Audit tidak berpengaruh terhadap Perataan Laba pada perusahaan Property dan Real Estate yang terdaftar di Bursa Efek Indonesia (BEI) dan perusahaan malaysia (KLSE) tahun 2014 sampai dengan tahun 2017 dikarenakan hipotesis lebih besar dari 0.05 . penelitian ini didukung oleh penelitan yang dilakukan oleh Lidiawati dan Asyik (2016) yang menyatakan bahwa kualitas audit tidak berpengaruh signifikan terhadap perataan laba. Dikarenakan seorang auditor dalam melaksanakan tugas sebagai auditor harus independen dan sesuai dengan etika seorang auditor. Tetapi berbeda dengan penelitian yang dilakukan oleh Marpaung dan Latrini (2014) kualitas audit yang diukur dengan ukuran KAP berpengaruh signifikan terhadap praktik perataan laba. Karena KAP yang memiliki reputasi yang baik seperti KAP big-four akan mampu mendeteksi kesalahan dalam laporan keuangan. Tetapi, penelitian ini dari perusahaan indonesia dan perusahaan malaysia tidak terdapat pengaruh variabel kualitas audit terhadap perataan laba. Penelitian ini didukung oleh penelitian yang dilakukan oleh Ingrid \& Yeterina bahwa kualitas audit tidak berpengaruh terhadap manajemen laba. Hal ini dimungkinkan praktik manajemen laba terjadi karena perusahaan memiliki keinginan agar kinerja keuangan perusahaan tampak bagus dimata calon investor, namun mengabaikan keberadaan auditor Big- 4 (Luhgiatno 2010).

Hasil uji Wald untuk variabel kepemilikan manajerial, perusahaan property dan real estate Indonesia memiliki nilai probabilitas sebesar 0.6425 dan perusahaan property dan real estate Malaysia memiliki nilai probabilitas sebesar 0.0177. Hal ini membuktikan bahwa nilai probabilitas indonesia lebih besar dari cut fif uji hipotesis sebesar 0,05 maka diterima. Namun, berbeda dengan hasil dari profabilitas malaysia yang membuktikan bahwa nilai probabilitas perusahaan property dan real estatemalaysia lebih kecil dari cut off uji hipotesis sebesar 0,05 dengan nilai koefisien dari analisis regresi logistik binary1.605851, Maka ditolak.

Hasil pengujian hipotesis menggunakan analisis regresi logistik binarydengan uji wald menunjukkan bahwa variabel kepemilikan manajerial perusahaan property dan real estate mulai tahun 2014 sampai dengan tahun 2017 tidak berpengaruh terhadap perataan laba. Sedangkan, variabel kepemilikan manajerial perusahaan property dan real estate malaysia mulai tahun 2014 sampai dengan tahun 2017 berpengaruh terhadap perataan laba. Penelitian ini didukung oleh penelitian yang dilakukan Nazira \& Ariani (2016) yang menyatakan bahwa kepemilikan manajerial berpengaruh terhadap pecataan laba.Menurut Marpaung dan Latrini (2014) walaupun manajemen secara aktif ikut mengambil keputusan karena saham yang dimilikinya, jumlah yang dimiliki oleh manajemen tersebut tidak terlalu besar berdampak terhadap suara yang diberikan dalam pengambilan keputusan yang berkaitan dengan perusahaan yang berkaitan dengan manipulasi laba.

Hasil uji Wald untuk variabel Dividen Payout Ratio, perusahaan property dan real estate Indonesia memiliki nilai probabilitas sebesar 0.4932 dan perusahaan property dan real estate Malaysia memiliki nilai probabilitas sebesar 0.4454 hipotesis sebesar 0,05 maka diterima.

Hasil pengujian hipotesis menggunakan analisis regresi logistik binarydengan uji wald menunjukkan bahwa variabel kepemilikan manajerial Audit tidak berpengaruh terhadap Perataan Laba pada perusahaan Property dan Real Estate yang terdaftar di Bursa Efek Indonesia (BEI) dan perusahaan malaysia (KLSE) tahun 2014 sampai dengan tahun 2017 dikarenakan hipotesis lebih besar dari 0.05. penelitian ini didukung oleh Kustono (2009) yang menyatakan tidak berhasil membuktikan bahwa dividend payout ratio berpengaruh terhadap perataan laba.Dalam teori keagenan manajer adalah pihak yang diberi wewenang untuk menjalankan perusahaan sesuai dengan keinginan dan untuk kepentingan pemegang 
saham.Keinginan dari pemegang saham adalah perusahaan mempunyai kinerja baik yang dapat tercermin dari laba yang dihasilkan setiap periodenya, kestabilan laba menunjukkan kestabilan kinerja dan mampu menghadapi resiko yang ada.Hal tersebut dapat memungkinkan manajemen untuk melakukan perataan laba. Namun, peneliti tidak dapat membuktikan bahwa Dividend Payout Ratio berpengaruh terhadap perataan.

\section{KESIMPULAN, KETERBATASAN DAN SARAN}

Berdasarkan penelitian ini, dapat disimpulkan bahwa: 1) Dewan komisaris independen tidak berpengaruh terhadap perataan laba yang terdaftar Di Bursa Efek Indonesia; 2) Komite Audit tidak berpengaruh terhadap perataan laba yang terdaftar di Bursa Efek Indonesia; 3) Kualitas Audit tidak berpengaruh terhadap perataaan laba yang terdaftar di Bursa Efek Indonesia; 4) kepemilikan manajerial tidak berpengaruh terhadap perataan laba yang terdaftar di Bursa Efek Indonesia; 5) Dividend payout Ratio tidak berpengaruh terhadap perataan laba yang terdaftar di Bursa Efek Indonesia; 6) Dewan komisaris independen tidak berpengaruh terhadap perataan laba yang terdaftar di Bursa Malaysia; 7) Komite Audit tidak berpengaruh terhadap perataan laba yang terdaftar di Bursa Malaysia; 8) Kualitas Audit tidak berpengaruh terhadap perataaan laba yang terdaftar di-Bursa Malaysia; 9) kepemilikan manajerial berpengaruh terhadap perataan laba yang terdaftar di Bursa Malaysia; 10) Dividend payout Ratio tidak berpengaruh terhadap perataan laba yang terdaftar di Bursa Malaysia. Dalam penelitian ini peneliti memakai Variabel Ukuran Perusahaan yaitu sebagai variabel kontrol perusahaan sektor property dan real estate yang terdaftar di Bursa Efek Indonesia (BEI) dan Bursa Malaysia tahun 2014 sampai dengan 2017 yaitu untuk melengkapi atau mengkontrol hubungan kausalnya supaya lebih baik untuk didapatkan model empiris yang lebih lengkap dan lebih baik. Dalam hal ini ukuran perusahaan tidak berpengaruh terhadap perataan sedangkan variabel ukuran perusahaan yang terdaftar di Bursa Malaysia (KLSE) berpengaruh terhadap perataan laba. Hal ini menunjukkan bahwa semakin besar ukuran perusahaan maka perusahaan tersebut cenderung akan melakukan perataan laba karena perusahaan yang memiliki total asset yang besar cenderung diperhatikan oleh investor, pemerintah dan publik.

Adapun saran yang diberikan untuk|perusahaa adalah diharapkan hasil penelitian ini dapat digunakan sebagai bahan pertimbangan bahma perusahaan dengan size besar mempunyai insentif yang besar untuk melakukan perataan laba dibandingkan dengan perusahaan kecil, karena perusahaan yang memiliki aktiva dalam jumlah besar akan lebih diperhatikan oleh publik dan pemerintah. Oleh karena itu perusahaan besar akan menghindari kenaikan laba secara drastis supaya terhindar dari kenaikan pembebanan biaya oleh pemerintah. Sebaliknya penurunan laba secara drastis memberikan sinyal bahwa perusahaan dalam masa krisis.

Saran untuk investor diharapkan penelitian ini dapat digunakan sebagai bahan evaluasi terhadap kualitas audit karena hasil audit dari KAP Big-4 yang memiliki kecenderungan dapat mendeteksi atau mengungkapkan praktik perataan laba padaperusahaan. Hal initerjadi karena auditor di KAP Big-4 memiliki kompetensi yang lebih baik dibandingkan dengan auditor pada KAP Non Big-4. Untukitu, disarankanbagi KAP Big-4 agar lebih teliti dalam mengungkapkan laporan keuangan kliennya sehingga, dapat meningkatkan kualitas audit. Karena kualitas audit yang baik akan mampu mendeteksi atau mengungkapkan praktik perataan laba dan mampu meminimalisir praktik perataan laba yang terjadi diperusahaan.

Saran untuk Peneliti selanjutnya diharapkan dapat menambahkan atau mengganti variable independen lain yang diduga dapat mempengaruhi perusahaan dalam melakukan praktik perataan laba dan dapat melakukan penelitian dengan menggunakan sampel selain 
perusahaan Sektor Property dan Real Estate yang terdaftar di Bursa Efek Indonesia dan Bursa Malaysia seperti sektor jasa,sektor manufaktur,sektor infrastruktur, sektor pertambangan, dan lainnya.

\section{REFERENSI}

Ajija, Shochrul R. 2011. Cara Cerdas Menguasai Eviews.Salemba Empat. Jakarta

Alves, Sandra. (2012). Ownership Structure and Earning Management: Evidencefrom Portugal. Australian Accounting Business and Finance Journal,Volume 6(1), 57-74.

Arens, Alvin A., Elder, Randal J., Beasly, Mark S., dan Jusuf, Amir Abadi. (2013). Jasa Audit dan Assurance: Pendekatan Terpadu (Adaptasi Indonesia) Jakarta: Erlangga.

Butar-Butar, L., K., \& Sudarsi, S. (2012). Pengaruh Ukuran Perusahaan, Leverage, Profitabilitis, dan Kepemilikan Institusional Terhadap Perataan Laba: Studi Empiris Pada Perusahaan Food and Beverages yang Terdaftar di BEI. Dinamika Akuntansi, Keuangan dan Perbankan, Vol. 1 No.2, ISSN: 1979 - 4878. Christiani, I., \& Nugrahanti, Y., W. (2014). Pengaruh Kualitas Audit Terhadap Manajemen
Laba. Jurnal Akuntansi dah Keuangan Vol 16 No. 1,ISSN: 1411-0288.

Gerayli, et al. (2011). Impact of Audit Quality on Earnings Management: Evidence from Iran. International Research Journat of Finance and Economics, ISSN: 1450-2887.

Jensen, M., C., \&Meckling, W. H. (1976). Theory of the Firm: Managerial Behaviour, Agency Costs, and Ownership Structure. Journal of Financial Economic Vol.3 No. 4,
1981, pp. 305-360.

Johari, N., H., Saleh, N., M., Joffar, R., \& Hassan M., S. (2008). The Influence of Board Independence, Competency and Ownership on Earnings Management: Evidence From Malaysia. Journal of Econonics and Management 2 (2): 281 - 306, ISSN 1823 $836 \mathrm{X}$

Kelerek, Astohar. (2014). Analisis Faktor-Faktor Yang Mempengaruhi Perataan Laba Studi Empiris Di Perusahaan Manufaktur Yang Terdaftar Di BEI. Jurnal Ilmu Manajemen dan Akuntansi TerapanVol 5 No. 2, November 2014.

Kharisma, A. dan Agustina, L. (2015). Pengaruh Mekanisme Corporate Governance Dan Ukuran Perusahaan Terhadap Praktik Perataan Laba. Accounting Analysis Journal 4 (2), ISSN 2252-6765

Marpaung, C., O., \& Latrini, N., M., Y. (2014). Pengaruh Dewan Komisaris Independen, Komite Audit, Kualitas Audit dan Kepemilikan Manajerial terhadap Perataan Laba. EJurnal Akuntansi Universitas Udayana 7.2: 279-289, ISSN:2302-8556.

Nabila, Afifa, dan Daljono. Pengaruh Proporsi Dewan Komisaris Independen, Komite Audit, dan Reputasi Auditor Terhadap Manajemen Laba. E-Journal Volume 2, Nomor 1, Tahun 2013, Halaman 1-10 
Nazira, C., F dan Ariani, N., E. (2016). Pengaruh Jenis Industri, Kepemilikan Manajerial, Operating Profit Margin Dan Dividend Payout Ratio Terhadap Perataan Laba. Jurnal Ilmiah Mahasiswa Ekonomi Akuntansi Vol. 1, No. 1, Hal 158-170.

Pratama, Dika Fajar. (2012). Pengaruh Profitabilitas, Resiko Keuangan, Nilai Perusahaan, Struktur Kepemilikan, dan Dividend Payout Ratio Terhadap Perataan Laba. Jurnal Akuntansi \& Investasi Vol.13, No.1.

Sekaran, Uma. (2011). Metodologi Penelitian untuk Bisnis (Buku II). Jakarta: Salemba Empat.

Subramanyam, K.R., dan Wild, John J. (2010). Analisis Laporan Keuangan. (Buku I).Jakarta: Salemba Empat.

Sugiyono. (2014). Metode Penelitian Kuantitatif Kualitatif dan Kombinasi (MixedMethods). Bandung: Alfabeta.

Sulistyanto, H., S. (2008). Manajemen laba: Teori dan Model Empiris. Jakarta, Grasindo.

Suwardjono, (2014).Teori III).Yogyakarta: BPFE.

Widaryanti. (2009). Analisis P Perusahaan Manufaktur

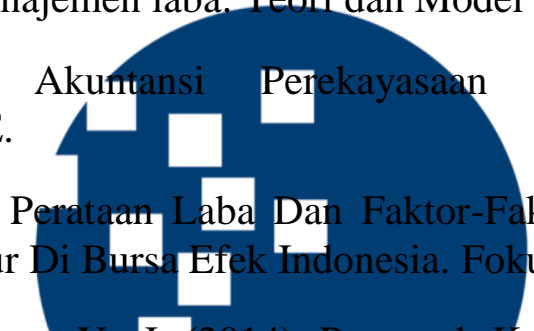

Laporan Keuangan. (Edisi ktor Yang Mempengaruhi Pada us Ekonomi, Volume 4, No.2.

Wijaya, V., A., dan Christiawan, Y., J. (2014). Pengaruh Kompensasi Bonus, Leverage dan Pajak Terhadap Manajemen Laba Pada Perusahaan Yang Terdaftar Di Bursa Efek Indonesia Tahun 2009-2013. Tax and Accounting Review Vol.4 No. 1.

Wijoyo, Dewi Sari (2014). Variabel-Variabel yang Mempengaruhi Praktik Perataan Laba pada Perusahaan Manufaktur yang Publik_Jurnal Bisnis dan Akuntansi Vol. 16, No. 1, Hlm. 37-45, ISSN: 1410-9875.

Yendriwati, Reni (2015). Pengaryh Dewan Komisaris Independen, Komite Audit Kepemilikan Manajerial, dan Kepemilikan Institusional terhadap Manajemen Laba pada perusahaan manufaktur yang terdaftar di Bursa Efek Indonesia tahun 2009 2013. Jurnal Entrepreneur dan Entrepreneurship, Volume 4, Nomor 1 dan 2, September 2015

http://www.idx.co.id/

http://www.bursamalaysia.com/market/ 